\title{
Degree of implementation of site management regulation (BNBC-93) in the construction site of Khulna city, Bangladesh
}

\author{
M. Rahman*, Md. J. Rabbani and Md. S. Uddin \\ Khulna University of Engineering \& Technology, Department of Building Engineering and Construction \\ Management, Khulna, Bangladesh
}

\begin{abstract}
The construction industry has a great impact on the economic growth of a country. Site management is an important issue to ensure efficient construction. Site management condition in construction industry in Bangladesh especially Khulna city still facing impediment as there is a deficiency of efficient implementation of Bangladesh National Building Code (BNBC) version 93. This study aims to identify the scenarios of site management practice according to BNBC-93 in the construction industry of Khulna city and identify the influencing factors for BNBC-93 adoption. The research has been carried out by a questionnaire survey where various stakeholders related to construction industry was participated. From the survey it was found that BNBC-93 rules on site management implementation rate are only $51 \%$ in Khulna city. According to this study, the main barriers to BNBC-93 rules adoption in construction site management are the lack of management support and negligence by relevant stakeholders. The lack of knowledge, behavior of workers and lack of law enforcement also act as significant barriers in this context. To increase the implementation of BNBC-93 rules on site management it is necessary to take action by the government agencies and increase awareness among all the stakeholders.
\end{abstract}

\section{Keywords}

Construction; Site management; Regulation; Barriers; BNBC

Received: 18 March 2019; Accepted: 26 June 2019

ISSN: 2630-5771 (online) @ 2018 Golden Light Publishing All rights reserved.

\section{Introduction}

One of the fastest and largest industry sector in Bangladesh is considered as building construction. During 1991-2006 periods it has been growing at 7.3 percent In terms of employment [1]. In recent year it has contributed $7.88 \%$ GDP to the national economy of Bangladesh [2, 3]. Total 2.024 million employees mounted in construction sector in 20082009. It will increase to 3.32 million by 2020 according to the current growth rate[1]. To accomplish controlled and focused result in the area where building or construction work is being carried out, whether it is within, adjacent to or discrete from an existing working building must have to used site management practice [4]. To maintain all work on site and foundation for a successful project, it is required some planning and facilities that are only provided by efficient site management practice [5]. The construction industry is growing in every city of Bangladesh as well as Khulna city remarkably, but site management regulation has not implemented accordingly to be needed. When compared with other industries in Bangladesh it is found that the structural safety 
conditions, environmental protection and the injury records are in worst condition in construction site [6]. The specification of BNBC-93 is not strictly followed in terms of design, execution in construction, as well as requirements for safety of the worker because of inexpert personnel in construction and many building owners are unwilling to pursue service of a professional engineer [1].

Site management is an important part of any construction industry which include dealing, working, managing and organize all requirements of a construction site. Over the last few decades, a consciousness of the significance of quality site management has been developing in the construction industry. So every personnel related in the construction industry are needed to aware and understanding whole site management regulation in order to achieve the quality of construction[7]. The main function of a site management team is to organize, inform, coordinate, order, instruct and motivate others to undertake site activities [8]. However, there are several challenging engineering and management problems that occur on the construction site. For instance, identified five major problems that are management support, poor communication, poor information, lack of knowledge and negligence by the stakeholder [9, 10]. Weather conditions, altered drainage, discrepancies between planned and as actual grades, financing, and unforeseen construction requirements and other variables combine to make construction site management challenging[11, 12]. Due to improper or lack of site management practices, different levels of work accidents ranging from minor injuries to fatal accidents have occurred and also causes economic loss and environmental pollution. A review of the relevant literature reveals that the status of the industry (in regard to site management) in developing countries is not promising, which is apparent from the low level of awareness and the lack of knowledge about BNBC93 regulation.

The review also found that the main factor hindering implementation of $\mathrm{BNBC}-93$ regulation in the construction industry are management support, negligence, behavior of worker, lack of knowledge and lack of law enforcement. It is necessary to present the real scenario of construction site management in Khulna city and take measure to overcome critical site management issues. Therefore, the aim of this study is to find the actual application rate of site management parameters during construction and identify the root causes for BNBC-93 adoption in construction sites of Khulna city, Bangladesh. This study also will able to find out the strength of BNBC-93 regulation for construction site management. If the real scenario comes to light, it will be easier for the authority to take effective necessary steps to improve the quality and standard of construction site management in Bangladesh. It is hoped that the outcomes of this study enrich knowledge about the current state of, driver of, and barriers to implement BNBC-93 regulation in Khulna City and form a significant base for future construction work within the country.

\section{About BNBC'93}

Bangladesh National Building Code (BNBC) is a building code regulated by Government of the Peoples Republic of Bangladesh. BNBC was first published in 1993 and BNBC 93 has been used as a reference in this research. BNBC 93 consist of three volume which is divided into ten parts. Each part consists of a few chapters. However, volume 3, Part 7 , Chapter 3 has been used in this study where title of the chapter is safety during construction. The relevant volume, part, chapter, and para has been shown in Table 1.

\section{Study area}

Khulna, the third largest city of Bangladesh, is located in the southern part of the country and is situated below the tropic of cancer, around the intersection of latitude $22.49 \mathrm{~N}$ and longitude 89.34E. The area of Khulna city is 47 square $\mathrm{km}$ with a population of 1.5 million (corporation 2018). This study was performed at six selected areas of Khulna city such as KUET (Khulna University of Engineering and Technology), Fulbarigate, Boira, 
Sonadanga, Nirala and New market. and the area has been represented in Fig. 1.

Table 1. Relevant segments of BNBC'93 of this study

\begin{tabular}{|c|c|c|c|c|c|}
\hline Issue & Volume & Part & Chapter & Para & Page \\
\hline 1. First aid kit. & 3 & 7 & 1 & 1.4 .2 & $7-3$ \\
\hline 2.Telephone for emergency contact & 3 & 7 & 1 & 1.4 .2 & $7-3$ \\
\hline 3. Temporary construction & 3 & 7 & 1 & 1.4 .3 & $7-3$ \\
\hline $\begin{array}{l}\text { 4. Plan, layout, design and specification of all temporary } \\
\text { constructions }\end{array}$ & 3 & 7 & 1 & 1.4 .3 & $7-3$ \\
\hline 5. Adequate storage. & 3 & 7 & 1 & 1.4 .4 & $7-4$ \\
\hline 6. Protection from weather & 3 & 7 & 1 & 1.4 .4 & $7-4$ \\
\hline 7. Vehicle easy access and exit & 3 & 7 & 1 & 1.4.5.2 & $7-4$ \\
\hline 8. Adequate yard lighting & 3 & 7 & 1 & 1.4.5.2 & $7-4$ \\
\hline 9. Effective drainage plan & 3 & 7 & 1 & 1.4.5.2 & $7-4$ \\
\hline 10. Fencing, barricades and signage & 3 & 7 & 1 & 1.4.5.2 & $7-4$ \\
\hline 11. Layout of temporary services & 3 & 7 & 1 & 1.4.5.2 & $7-4$ \\
\hline 12. Construction safety with emergency access & 3 & 7 & 1 & 1.4.5.2 & $7-4$ \\
\hline 13. Free access from the street to fire hydrant. & 3 & 7 & 1 & 1.4.5.3 & $7-5$ \\
\hline 14. Stairway & 3 & 7 & 1 & 1.4.5.3 & $7-5$ \\
\hline 15. Ensuring slope stability & 3 & 7 & 1 & 1.4.5.4 & $7-5$ \\
\hline 16. Installation of cranes and piling equipment. & 3 & 7 & 1 & 1.4.5.4 & $7-5$ \\
\hline 17. Protection against ground water seepage. & 3 & 7 & 1 & 1.4.5.4 & $7-5$ \\
\hline 18. Personnel protective equipment. & 3 & 7 & & & \\
\hline 19. Monitoring and controls during project. & 3 & 7 & 3 & 3.2 .1 & $7-30$ \\
\hline 20. Protection adjoining structures & 3 & 7 & 1 & 1.7 .1 & $7-8$ \\
\hline 21. The permission of the adjoining property owner. & 3 & 7 & 1 & 1.7 .2 & $7-8$ \\
\hline 22. Protective fence and railing & 3 & 7 & 1 & 1.7 .3 & $7-9$ \\
\hline 23. Adequate strength to resist wind pressure. & 3 & 7 & 1 & 1.7 .3 & $7-9$ \\
\hline 24. Protective frame and boarding & 3 & 7 & 1 & 1.7 .5 & $7-9$ \\
\hline 25. Precaution during construction & 3 & 7 & 1 & 1.7 .5 & $7-9$ \\
\hline 26. Permissions from authorities & 3 & 7 & 1 & 1.7.6 & $7-10$ \\
\hline 27. Clear passage along the building site & 3 & 7 & 1 & 1.7 .6 & $7-10$ \\
\hline 28. Walkway keep well-lighted at night & 3 & 7 & 1 & 1.7 .8 & $7-10$ \\
\hline 29. Signs and emergency instructions. & 3 & 7 & 1 & 1.7 .8 & $7-10$ \\
\hline 30. Watchman. & 3 & 7 & 1 & 1.7 .9 & $7-10$ \\
\hline 31. Audible signal & 3 & 7 & 1 & 1.7 .9 & $7-10$ \\
\hline 32. Existing underground utility lines & 3 & 7 & 1 & 1.8 .1 & $7-11$ \\
\hline $\begin{array}{l}\text { 33. Permission from the respective authorities before } \\
\text { excavation }\end{array}$ & 3 & 7 & 1 & 1.8 .1 & $7-11$ \\
\hline 34. Housekeeping & 3 & 7 & 2 & 2.1 .4 & $7-14$ \\
\hline 35. Adequate sanitary facilities & 3 & 7 & 3 & 3.2 .3 & $7-30$ \\
\hline 36. Minimize dust-blow & 3 & 7 & 1 & 1.8 .3 & $7-11$ \\
\hline 37. Noisy activities & 3 & 7 & 1 & 1.8 .4 & $7-12$ \\
\hline 38. Good site practices & 3 & 7 & 1 & 1.8 .5 & $7-12$ \\
\hline
\end{tabular}




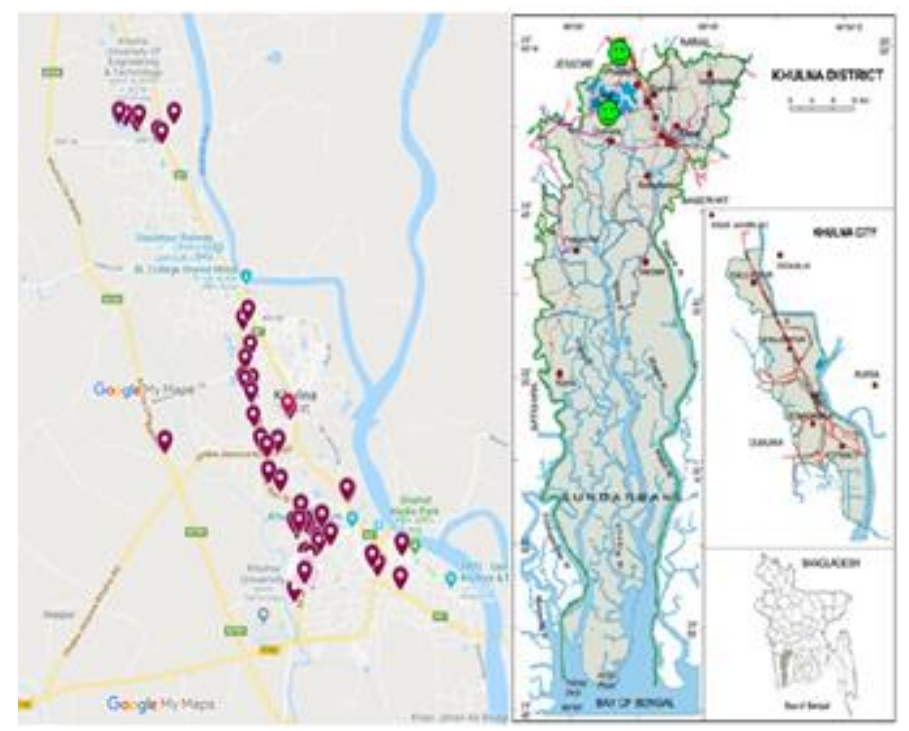

Fig. 1. Location of study areas in Khulna city area of Bangladesh.

\section{Research methodology}

The study had been conducted through several phases namely literature review, review of existing laws, data collection and analysis, application of statistical tools for analysis of survey data. Then the influencing factors were identified, and finally this study provided some suggestions and recommendations. Fig. 2 represents the overall process of the study.

\subsection{Questionnaire design}

In order to fulfill the objectives of the study, all around organized close-ended questionnaires were designed to assemble data from the respondents. These questions were ethical and feasible. The wordings were without bias and the questions provided multiple choice options which gave the respondents the opportunity to present their ideas by the way of selecting from the options provided. The sample questionnaire form that has been conducted can be seen in Fig. 3 .

In most of the questions in the questionnaire survey, the contractor, engineers, project managers, and the workers were the respondents where they have provided their opinion according to their own construction site to each statement. Two types of question such as Yes or No has been. If any respondent were choosing No option, then they also choose the option behind the reasons that found from background information collection. This study mainly focused on the construction site management part, according to BNBC -93(Volume 3, Part 7, Chapter 1, Page No 3-13) and assess whether the BNBC regulations implement or not. For this purpose 38 major issues of site management regulation was chosen from BNBC93. Issues are related to first aid attendant, temporary construction, access for firefighting equipment vehicles, construction strategy and construction sequence, health, and safety environment, adjoining property, protective fences and railings, protection of utilities, use of road and footpath, notices and signs, watchman and auditory signal, protection of soil, aquifers, and water channels against pollution, protection from air and sound pollution, housekeeping, site security, use of personal protective equipment etc. 5 major barriers set on the questionnaire (lack of management support, Negligence, behavior of workers, lack of knowledge, lack of law enforcement) based on the literature review. 


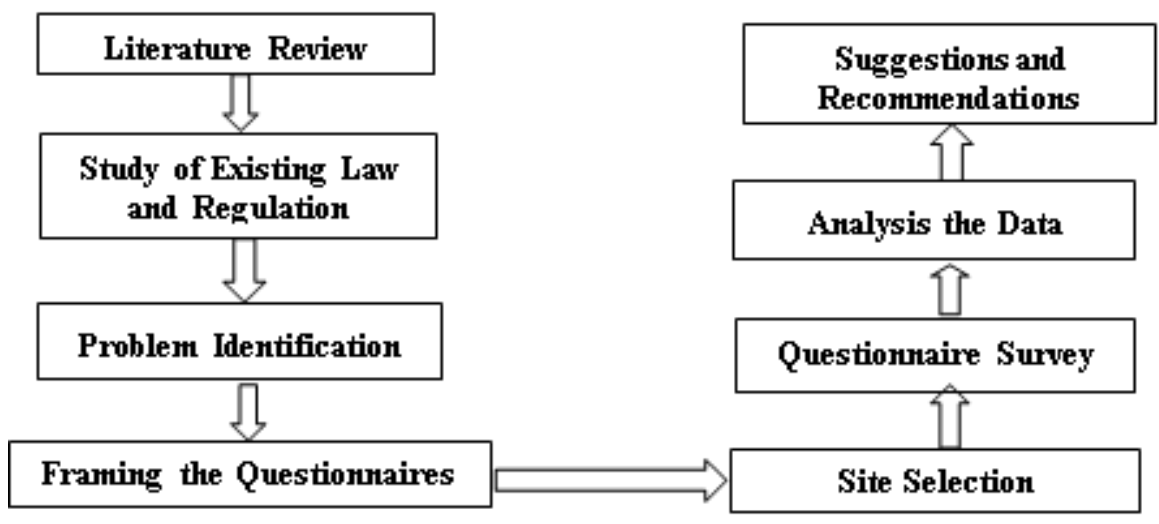

Fig. 2. Overall process of the study

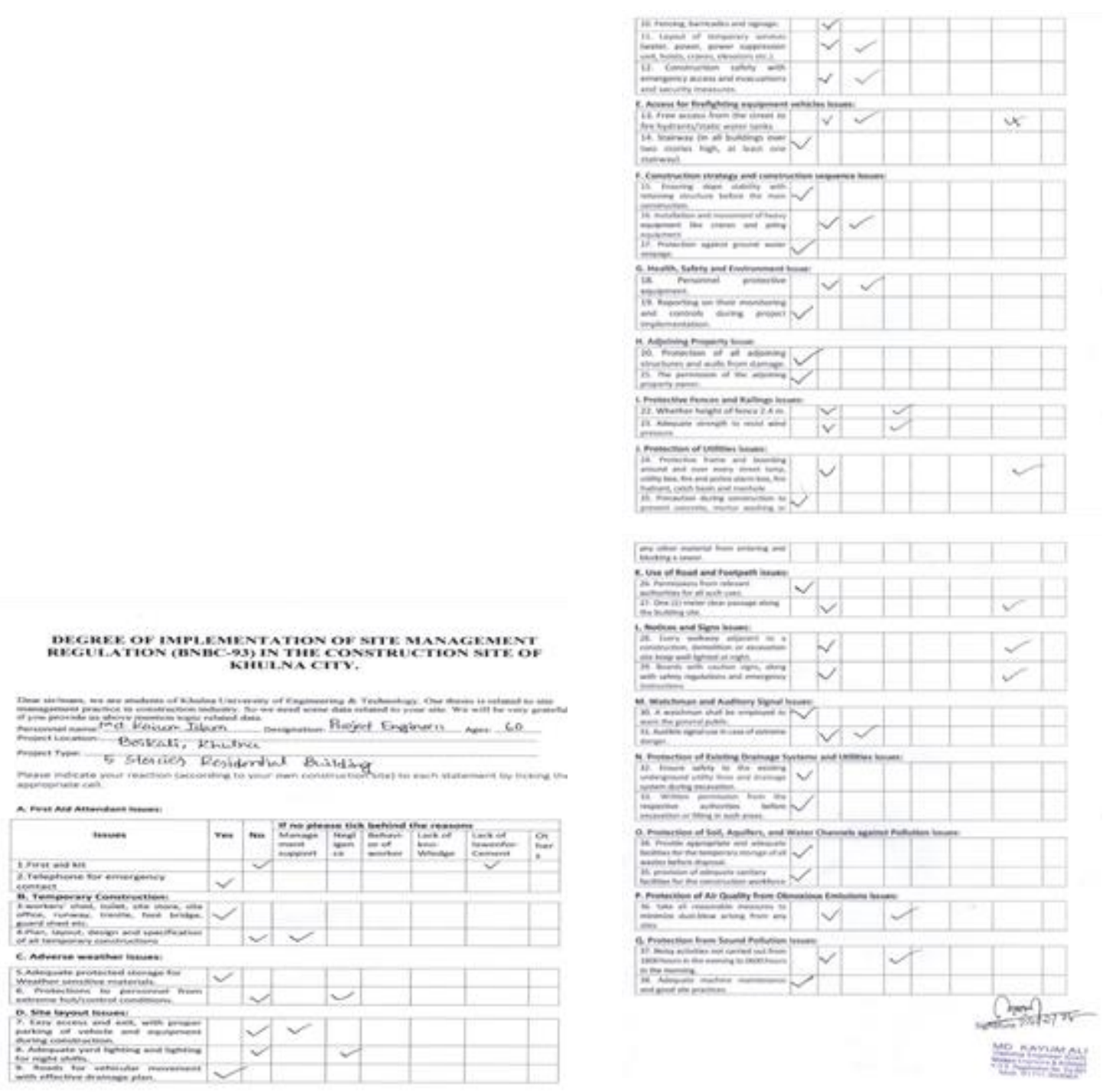

Fig. 3. Sample questionnaire form 


\subsection{Data collection}

The date was collected main from construction site of different parts of Khulna city in order to get a general scenario of the construction sites of Khulna city. Around 100 sites were selected randomly from both developed areas and suburban areas. Two groups were classified to conduct the survey. Group-1 covered the workers and foremen. The other group, group-2 covered the employer's side which constituted site engineers, project managers, and contractors.

\subsection{Data analysis}

The statistics have been analyzed via SPSS software program and MS Excel. The frequency, percent, valid percent and cumulative percent of that data were determined against 38 issues of site management. The one sample of data analysis shown in Table 2.

\section{Result and discussion}

\subsection{Present scenario of adoption of BNBC-93 regulations}

From the site survey it has been found that proper site management practices that has been regulated in BNBC'93 is below the satisfactory level in the construction site of Khulna city area. The current scenario has been represented in the Figs. 4-9.

Table 3 represent the degree of implantation of 38 nos. of BNBC-93 regulation on construction site management for instance first aid implementation rate is only $44 \%$, telephone for emergency contact is used only $21 \%$ site etc. Overall, Fig. 10 shown the graphical representation of implementation status of the BNBC-93 regulation where 51\% regulations have been adopted and $49 \%$ regulations did not implemented.

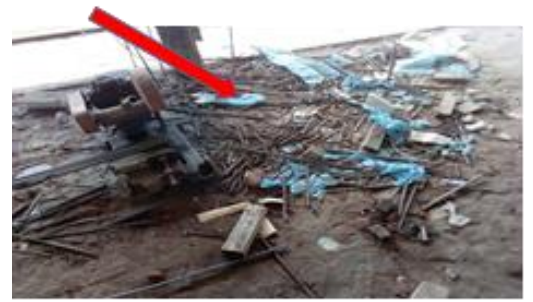

Fig. 4. Lack of waste management system

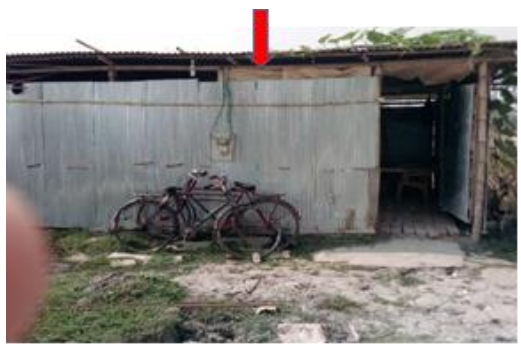

Fig. 5. Unplanned location of site office

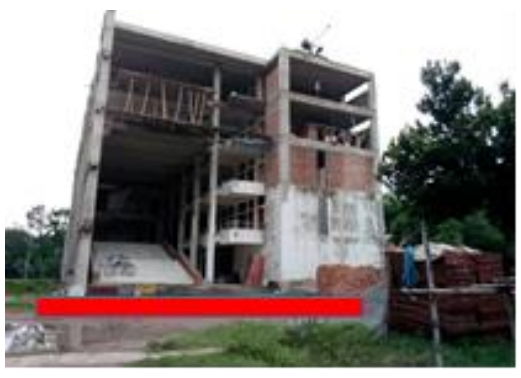

Fig. 6. No hoarding or barricade and safety sign provided

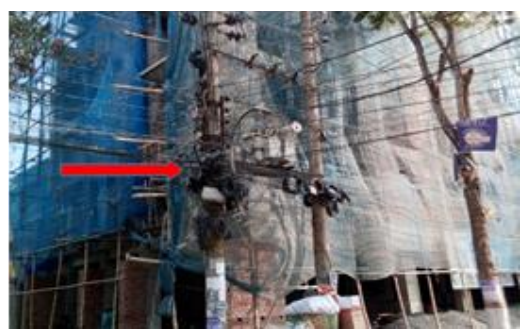

Fig. 7. No protection for street lamp, electric post

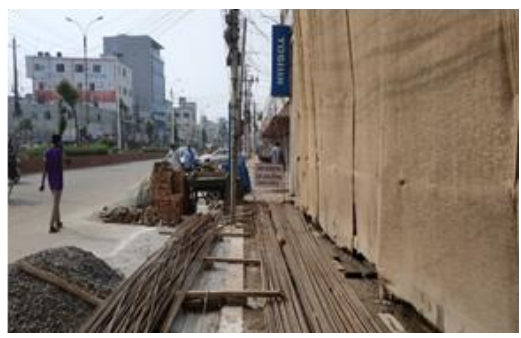

Fig. 8. The construction material placed on public road

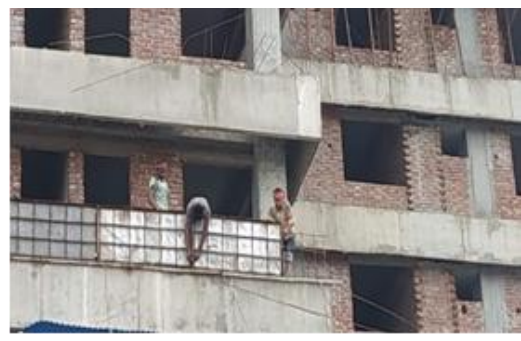

Fig. 9. Not using of PPE 
Table 2. Survey response for first aid kit

\begin{tabular}{llcccc}
\hline & & & & Cumulative \\
& & Frequency & Percent & Valid Percent & Percent \\
\hline \multirow{4}{*}{ No } & Management support & 34 & 34.0 & 60.7 & 60.7 \\
& Negligence & 13 & 13.0 & 23.2 & 83.9 \\
& Lack of knowledge & 4 & 4.0 & 7.1 & 91.1 \\
& Lack of law enforcement & 4 & 4.0 & 7.1 & 98.2 \\
& Others & 1 & 1.0 & 1.8 & 100.0 \\
\multirow{2}{*}{ Yes } & Total & 56 & 56.0 & 100.0 & \\
\hline Total & & 44 & 44.0 & & \\
\hline
\end{tabular}

Table 3. Degree of implantation of various site management issues according to BNBC

\begin{tabular}{|c|c|c|c|}
\hline Issues (major site management regulation) & $\begin{array}{l}\text { Implement } \\
(\%)\end{array}$ & $\begin{array}{c}\text { Not implement } \\
(\%)\end{array}$ & Total \\
\hline 1. First aid kit. & 44 & 56 & 100 \\
\hline 2.Telephone for emergency contact & 21 & 79 & 100 \\
\hline 3. Temporary construction & 66 & 34 & 100 \\
\hline $\begin{array}{l}\text { 4. Plan, layout, design and specification of all temporary } \\
\text { constructions }\end{array}$ & 7 & 93 & 100 \\
\hline 5. Adequate storage. & 63 & 37 & 100 \\
\hline 6. Protection from weather & 5 & 95 & 100 \\
\hline 7. Vehicle easy access and exit & 56 & 44 & 100 \\
\hline 8. Adequate yard lighting & 85 & 15 & 100 \\
\hline 9. Effective drainage plan & 16 & 84 & 100 \\
\hline 10. Fencing, barricades and signage & 41 & 59 & 100 \\
\hline 11. Layout of temporary services & 5 & 95 & 100 \\
\hline 12. Construction safety with emergency access & 51 & 49 & 100 \\
\hline 13. Free access from the street to fire hydrant. & 72 & 28 & 100 \\
\hline 14. Stairway & 99 & 1 & 100 \\
\hline 15. Ensuring slope stability & 75 & 25 & 100 \\
\hline 16. Installation of cranes and piling equipment. & 36 & 64 & 100 \\
\hline 17. Protection against ground water seepage. & 82 & 18 & 100 \\
\hline 18. Personnel protective equipment. & 14 & 86 & 100 \\
\hline 19. Monitoring and controls during project. & 76 & 24 & 100 \\
\hline 20. Protection adjoining structures & 74 & 26 & 100 \\
\hline 21. The permission of the adjoining property owner. & 89 & 11 & 100 \\
\hline 22. Protective fence and railing & 25 & 75 & 100 \\
\hline 23. Adequate strength to resist wind pressure. & 28 & 72 & 100 \\
\hline 24. Protective frame and boarding & 22 & 78 & 100 \\
\hline
\end{tabular}


Table 3. Cont'd

\begin{tabular}{llll} 
25. Precaution during construction & 78 & 22 & 100 \\
26. Permissions from authorities & 92 & 8 & 100 \\
27. Clear passage along the building site & 38 & 62 & 100 \\
28. Walkway keep well-lighted at night & 85 & 15 & 100 \\
29. Signs and emergency instructions. & 21 & 79 & 100 \\
30. Watchman. & 85 & 15 & 100 \\
31. Audible signal & 7 & 93 & 100 \\
32. Existing underground utility lines & 67 & 33 & 100 \\
33. Permission from the respective authorities before excavation \\
34. Housekeeping & 65 & 35 & 100 \\
35. Adequate sanitary facilities & 55 & 45 & 100 \\
36. Minimize dust-blow & 75 & 25 & 100 \\
37. Noisy activities & 8 & 92 & 100 \\
38. Good site practices & 44 & 56 & 100 \\
Cumulative (\%) & 72 & 28 & 100 \\
Total (\%) & 1944 & 1856 & 100 \\
\hline
\end{tabular}

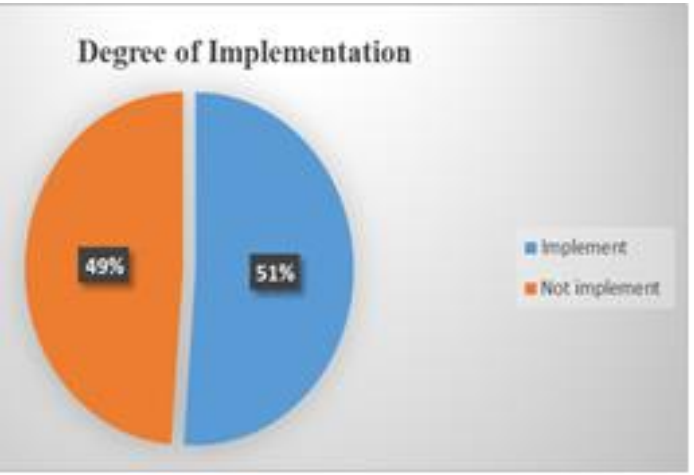

Fig. 10. Overall degree of adoption of BNBC'93 regulations

\subsection{Barriers and their impact on $B N B C^{\prime} 93$ implementation}

Table 4 represented the main obstacle for implementing BNBC-93 and their negative impact on each site management issues. The main impairment of first aid kit implementation is lack of management support where $60.7 \%$ of the management are not supporting the adoption of site management regulations that has been incorporated in BNBC'93.Similarly, the major obstacle for utilization of telephone for emergency contact is negligence of owners, contractors, engineers, workers and other stakeholders and the magnitude is $49.4 \%$.The rest of the survey results has been represented in the Table 4.

\subsection{Overall barriers impact on site management}

Fig. 11 represented among the six barriers, lack of management support around $34.9 \%$ and negligence (by contractors, Engineers, Owners, Workers and other stakeholders) around $34.6 \%$ are the main impediments of site management. Behaviors of workers, lack of knowledge and lack of knowledge also have a great negative impact on BNBC'93 rules adoption in site management. Other barriers like lack of inspection, lack of training, tight schedule also have a good impact.

\section{Conclusion and recommendations}

This research upholds the real scenario of site management practice according to BNBC-93 and the principle impediment and their negative impact on the adoption of site management regulations that have been regulated in the BNBC-93.The data were collected from various stakeholders for instance Engineers, Contractors, Workers, Owners, and Architects through a questionnaire survey. 
Table 4. Root causes and their negative impact on BNBC-93 adoption

\begin{tabular}{|c|c|c|c|c|c|c|c|}
\hline No & Issues & $\begin{array}{l}\text { Management } \\
\text { Support (\%) }\end{array}$ & $\begin{array}{l}\text { Negligence } \\
(\%)\end{array}$ & $\begin{array}{c}\text { Behavior } \\
\text { of } \\
\text { Worker } \\
(\%)\end{array}$ & $\begin{array}{c}\text { Lack of } \\
\text { Knowledge } \\
(\%)\end{array}$ & $\begin{array}{l}\text { Lack of law } \\
\text { Enforcement } \\
(\%)\end{array}$ & $\begin{array}{c}\text { Others } \\
(\%)\end{array}$ \\
\hline 1 & First aid kit & 60.7 & 23.2 & 0 & 7.1 & 7.2 & 1.8 \\
\hline 2 & $\begin{array}{l}\text { Telephone for emergency } \\
\text { contact }\end{array}$ & 46.8 & 49.4 & 0 & 0 & 1.3 & 2.5 \\
\hline 3 & Temporary construction & 79.4 & 14.7 & 0 & 0 & 5.9 & 0 \\
\hline 4 & $\begin{array}{l}\text { Plan, layout, design and } \\
\text { specification of all } \\
\text { temporary constructions }\end{array}$ & 45.2 & 35.5 & 0 & 6.5 & 11.7 & 1.1 \\
\hline 5 & Adequate storage & 67.7 & 18.9 & 0 & 0 & 2.7 & 10.8 \\
\hline 6 & Protection from weather & 34.7 & 50.5 & 2.1 & 7.4 & 1.1 & 4.2 \\
\hline 7 & $\begin{array}{l}\text { Vehicle easy access and } \\
\text { exit }\end{array}$ & 72.7 & 9.1 & 0 & 4.5 & 11.4 & 2.3 \\
\hline 8 & Adequate yard lighting & 20 & 60 & 0 & 0 & 13.3 & 6.7 \\
\hline 9 & Effective drainage plan & 34.5 & 8.3 & 0 & 35.7 & 15.5 & 6 \\
\hline 10 & $\begin{array}{l}\text { Fencing, barricades and } \\
\text { signage }\end{array}$ & 15.3 & 32.2 & 0 & 5.1 & 32.2 & 15.2 \\
\hline 11 & $\begin{array}{l}\text { Layout of temporary } \\
\text { services }\end{array}$ & 38.9 & 41.1 & 0 & 13.7 & 5.3 & 1 \\
\hline 12 & $\begin{array}{l}\text { Construction safety with } \\
\text { emergency access }\end{array}$ & 30.6 & 34.6 & 0 & 10.2 & 20.5 & 4.1 \\
\hline 13 & $\begin{array}{l}\text { Free access from the street } \\
\text { to fire hydrant. }\end{array}$ & 57.2 & 10.7 & 0 & 3.6 & 21.4 & 7.1 \\
\hline 14 & Stairway & 100 & 0 & 0 & 0 & 0 & 0 \\
\hline 15 & Ensuring slope stability & 12 & 44 & 0 & 4 & 28 & 12 \\
\hline 16 & $\begin{array}{l}\text { Installation of cranes and } \\
\text { piling equipment }\end{array}$ & 92.1 & 6.3 & 0 & 0 & 1.6 & 0 \\
\hline 17 & $\begin{array}{l}\text { Protection against ground } \\
\text { water seepage. }\end{array}$ & 38.3 & 33.3 & 0 & 5.6 & 5.6 & 16.7 \\
\hline 18 & $\begin{array}{l}\text { Personnel protective } \\
\text { equipment }\end{array}$ & 52 & 12.8 & 17.4 & 2.3 & 10.5 & 0 \\
\hline 19 & $\begin{array}{l}\text { Monitoring and controls } \\
\text { during project }\end{array}$ & 20.8 & 66.7 & 0 & 0 & 4.2 & 8.3 \\
\hline 20 & $\begin{array}{l}\text { Protection adjoining } \\
\text { structures }\end{array}$ & 3.8 & 57.7 & 0 & 0 & 38.5 & 0 \\
\hline 21 & $\begin{array}{l}\text { Permission of the adjoining } \\
\text { owner }\end{array}$ & 0 & 45.5 & 0 & 0 & 54.5 & 0 \\
\hline 22 & Protective fence and railing & 10.7 & 42.6 & 0 & 37.3 & 6.7 & 2.7 \\
\hline 23 & $\begin{array}{l}\text { Adequate strength to resist } \\
\text { wind pressure }\end{array}$ & 30.5 & 51.4 & 0 & 12.5 & 2.8 & 2.8 \\
\hline 24 & $\begin{array}{l}\text { Protective frame and } \\
\text { boarding }\end{array}$ & 14.1 & 51.3 & 0 & 7.7 & 25.6 & 1.3 \\
\hline 25 & $\begin{array}{l}\text { Precaution during } \\
\text { construction }\end{array}$ & 27.3 & 68.2 & 4.5 & 0 & 0 & 0 \\
\hline
\end{tabular}


Table 4. Cont'd

\begin{tabular}{|c|c|c|c|c|c|c|c|}
\hline 26 & $\begin{array}{l}\text { Permissions from } \\
\text { authorities }\end{array}$ & 37.5 & 0 & 0 & 0 & 50 & 12.5 \\
\hline 27 & $\begin{array}{l}\text { Clear passage along the } \\
\text { building site }\end{array}$ & 9.7 & 11.3 & 0 & 9.7 & 66.1 & 3.2 \\
\hline 28 & $\begin{array}{l}\text { Walkway keep well-lighted } \\
\text { at night }\end{array}$ & 20 & 53.4 & 0 & 0 & 13.3 & 13.3 \\
\hline 29 & $\begin{array}{l}\text { Signs and emergency } \\
\text { instructions }\end{array}$ & 16.4 & 24.1 & 0 & 19 & 36.7 & 3.8 \\
\hline 30 & Watchman & 53.4 & 33.3 & 0 & 0 & 13.3 & 0 \\
\hline 31 & Audible signal & 50.5 & 12.9 & 0 & 31.2 & 4.3 & 1.1 \\
\hline 32 & $\begin{array}{l}\text { Existing underground } \\
\text { utility lines }\end{array}$ & 6.1 & 24.2 & 0 & 18.2 & 15.2 & 36.3 \\
\hline 33 & $\begin{array}{l}\text { Permission from the } \\
\text { respective authorities } \\
\text { before excavation }\end{array}$ & 0 & 20 & 2.9 & 11.4 & 45.7 & 20 \\
\hline 34 & Housekeeping & 33.4 & 55.6 & 4.4 & 0 & 2.4 & 4.4 \\
\hline 35 & Adequate sanitary facilities & 60 & 28 & 4 & 0 & 0 & 8 \\
\hline 36 & Minimize dust-blow & 14.1 & 67.4 & 0 & 12 & 4.3 & 2.2 \\
\hline 37 & Noisy activities & 3.6 & 55.4 & 0 & 7.1 & 26.8 & 7.1 \\
\hline 38 & God site practices & 10.7 & 60.8 & 0 & 0 & 7.1 & 21.4 \\
\hline
\end{tabular}

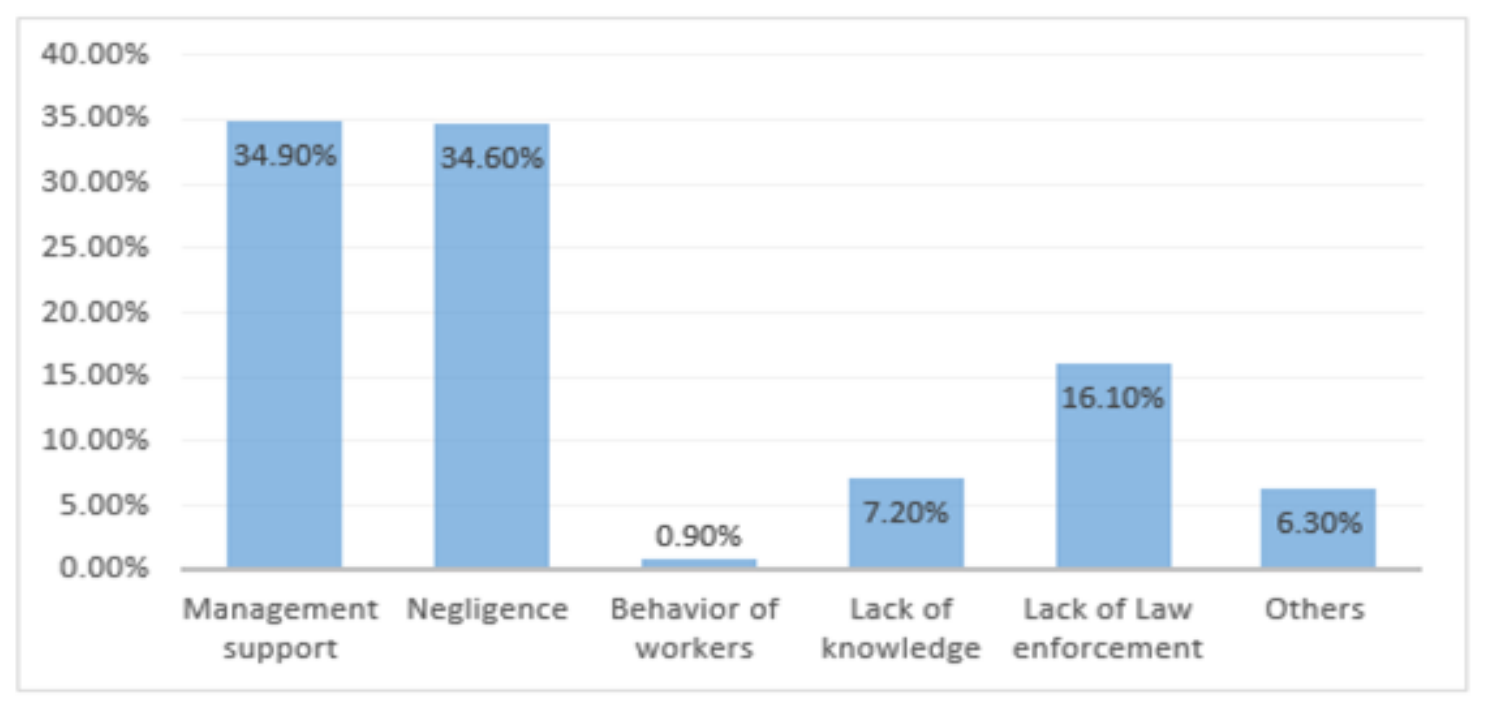

Fig. 11. Overall impact of major six impediment on site management in Khulna city

Major 38 nos. of site management regulations and 6 nos. of barriers were selected that has negative impact on BNBC-93 rules adoption in site management. In general, the site management related issues at present winning in the construction sites did not reflected a persuading and acceptable picture. This study identified that implementation rate of BNBC-93 rules on site management only
49\%. Among the barriers "lack of management support and negligence (by contractors, Engineers, Owners, Workers and other stakeholders)" are the main affecting impediments. On the other hand, "behaviors of workers and lack of knowledge" also have a significant negative impact on BNBC-93 rules adoption for managing site. From the survey it also been found that "lack of inspection, lack of 
training and tight schedule" have a significant negative impact on proper site management. From this research, it has been found that some site management issues like Earth Control Measure (ECM) and provision of washing bay can be added in the BNBC-93 code for better construction site management. This study was conducted in 100 construction sites located in Khulna city area of Bangladesh. However, more construction site need to be surveyed to find out the more accurate scenario of Khulna city. In addition, this survey was conducted with major 38 nos. of site management regulations and 6 major barriers that had been cited in the BNBC-93. However, in order to get more comprehensive results, more regulations and barrier can be incorporated in future study to get a more realistic result. Finally, it can be strongly recommended that the degree of implementation of site management regulation will increase if technology based site management such as Building Information Modeling (BIM) is implement in the construction site of Khulna city area of Bangladesh.

\section{Acknowledgments}

The authors would like to thanks all participants who have helped by providing their valuable time and opinion during the survey.

\section{References}

[1] Ahmed M, Siddiquee M, Khan M (2012). Reliability and Construction Practices in Building Construction Industry of Bangladesh, Third International Conference on Construction in Developing Countries (ICCIDC-III). Paper.

[2] Ahmed S, Hoque MI, Islam MH, Hossain M (2018). A Reality Check of Status Level of Worker against Skilled Worker Parameters for Bangladeshi Construction Industry, Journal of Civil Engineering and Construction 7: 132-132.

[3] Ahmed S, Islam MH, Hoque MI, Hossain M (2018). Reality check against skilled worker parameters and parameters failure effect on the construction industry for Bangladesh, Interntional Journal of Construction Management: 1-10.

[4] Dos Santos A, Powell JA, Sarshar MJMD (2002). Evolution of management theory: the case of production management in construction, Management Decision, 40(8): 788-796.

[5] Griffith A, Watson P. Construction management: Principles and practice, Macmillan International Higher Education, 2003.

[6] Hossain MM, Ahmed S (2018). A case study on safety assessment of construction project in Bangladesh, Journal of Construction Engineering 1(4): 147-156.

[7] Gray RW, Heuring VP, Levi SP, Sloane AM, Waite WMJ (1992) Eli: A complete, flexible compiler construction system, Communications of the ACM, 35(2): 121-132.

[8] Ashworth A, Perera S (2018). Contractual procedures in the construction industry, Routledge.

[9] Ahmed S (2019). Causes of Accident at Construction Sites in Bangladesh, Organization, Technology and Management in Construction 11.

[10] Barber P, Tomkins C, Graves AJIJoPM (1999). Decentralised site management - a case study, International Journal of Project Management, 17(2): 113-120.

[11] Ahmed S, Sobuz MHR, Haque MI (2018). Accidents on construction sites in Bangladesh: A review, in: D.K.H. Bari (Ed.) 4th International Conference on Civil Engineering for Sustainable Development (ICCESD 2018), Khulna University of Engineering \& Technology, KUET, Khulna, Bangladesh: 4599 (1-8).

[12] Hughes JD (2014). Environmental problems of the Greeks and Romans: ecology in the ancient Mediterranean, JHU Press. 